\title{
Basic suture techniques for medicine students: comparative results according to training by surgeons versus peers
}

\author{
Técnicas de sutura básicas para estudiantes de medicina: resultados comparativos \\ según entrenamiento por cirujanos versus pares
}

\begin{abstract}
Roberto González",2*, Héctor Molina², María García-Huidobro²,3, Patricio Stevens ${ }^{2,3}$, Andrés Jadue", Alejandra Riquelme ${ }^{4}$, Javier Torres ${ }^{4}$, Sebastián Barra ${ }^{5}$, Felipe Alarcón ${ }^{5}$ y Eduardo Fasce 6

${ }^{1}$ Cardiovascular Center, Regional Clinical Hospital of Concepción, "Dr. Guillermo Grant Benavente"; ${ }^{2}$ Department of Surgery, Faculty of Medicine, University of Concepción; ${ }^{3}$ Surgery Service, Regional Clinical Hospital of Concepción, "Dr. Guillermo Grant Benavente"; ${ }^{4}$ Department of General Surgery, Faculty of Medicine, University of Concepción; ${ }^{5}$ School of Medicine, Faculty of Medicine, University of Concepción; ${ }^{6}$ Department of Medical Education, Faculty of Medicine, University of Concepción. Concepción, Chile
\end{abstract}

\begin{abstract}
Objective: To compare the acquisition of basic procedural suture skills in medical students according to practical teaching by surgeons versus peers. Methods: Pre-experimental study before and after, a practical suture workshop was held for 46 eighth-semester medical students of the University of Concepción between November and December 2017. Participants were randomly distributed in such a way that half of them were trained by sub-specialists surgeons and the other by medical students (suture instructor). The continuous and discontinuous suture was evaluated on the biological model using the "the objective structured assessment of technical skills" (OSATS) scale. A satisfaction survey was applied at the end of the workshop. Results of the OSATS scale are compared before and after the workshop, SPSS24 ${ }^{\circledR}$ was used for statistical analysis by Student's $t$-test for independent samples, considering significant $p<0.05$. Results: Both groups progressed significantly on the OSATS scale (13.0 vs. 26.0, $p<0.001$ for surgeons and 16.8 vs. 27.9, $p<0.001$ for suture instructors) when comparing pre- versus post-workshop results, respectively. The post-workshop results do not show significant differences. Conclusion: Participants acquire basic surgical suture skills evidencing significant progression and similar degree of satisfaction regardless of whether they are trained by subspecialist surgeons or trained peers.
\end{abstract}

KEY WORDS: Medical student education. Technical skills. Medical education. Surgical education.

\section{Resumen}

Objetivo: Comparar la adquisición de habilidades básicas de sutura en estudiantes de medicina según la enseñanza práctica por cirujanos o por pares. Método: Estudio preexperimental antes y después. Se realizó un taller práctico de suturas para 46 estudiantes de medicina de octavo semestre de la Universidad de Concepción, entre noviembre y diciembre de 2017. Se distribuyó aleatoriamente a los participantes. La mitad de ellos fueron entrenados por cirujanos subespecialistas y la otra mitad por estudiantes de medicina (monitores de sutura). Se evaluaron la sutura continua y discontinua sobre un modelo biológico mediante la escala "The Objective Structured Assessment Of Technical Skills" (OSATS). Se aplicó una encuesta de satisfacción al finalizar el taller. Se comparan los resultados de la escala OSATS antes y después del taller. Se utilizó SPSS24 ${ }^{\oplus}$ para el análisis estadístico mediante la prueba t de Student para muestras independientes, y se consideró significativo un valor de $p<0.05$. Resultados: Ambos grupos progresaron significativamente en la escala OSATS al com-

\footnotetext{
Correspondencia:

*Roberto González Lagos

Janequeo Corner Chacabuco, $\mathrm{s} / \mathrm{n}$

C.P. 4030000, Concepción, Chile

E-mail: rgonzalezlagos@udec.cl
}

Fecha de recepción: 27-09-2018

Fecha de aceptación: 10-11-2018

DOI: $10.24875 / C I R U .18000771$
Cir Cir. 2019;87:624-629 www.cirugiaycirujanos.com 
parar los resultados antes y después del taller: 13.0 vs. $26.0(p<0.001)$ para cirujanos y 16.8 vs. $28.0(p<0.001)$ para monitores de sutura. Los resultados después del taller no presentan diferencias significativas. Conclusión: Los participantes adquieren habilidades básicas de sutura evidenciando una progresión significativa y similar grado de satisfacción independientemente de si son entrenados por cirujanos subespecialistas o por pares entrenados.

PALABRAS CLAVE: Educación de estudiantes de medicina. Competencias técnicas. Educación médica. Educación quirúrgica.

\section{Introduction}

The suture of wounds is one of the learning objectives that most interests students of medicine and are qualified as one of the most important surgical skills that they learn in undergraduate studies'. Despite its importance, a large part of the students is trained in suture technique when facing emergency situations or during their internship, mainly due to the lack of surgeons who teach these skills in a personalized way in previous subjects, which causes heterogeneous training among students and exposes patients to avoidable risks ${ }^{2-5}$.

Different schools of medicine have implemented programs of teaching suture techniques based on simulators that allow students the first approach to surgical procedures, sustained training over time, and effective feedback from experienced teachers ${ }^{6-8}$.

Clinical simulation not only allows the teaching of surgical skills in a controlled environment but also the evaluation of them with standardized guidelines, which determines minimum learning objectives, gives validity to the results obtained and allows the comparison of these between different series ${ }^{9-11}$.

Experiences show benefits by including assistant students in undergraduate education, demonstrating even that university students under tutoring of high school students can obtain the same academic performance as students guided by university teachers ${ }^{12}$.

Although several studies incorporate students as assistants in their surgical skills training programs, there is little evidence to support peer training as equally effective as by teachers in acquiring basic suture techniques.

The objective of this work is to compare the acquisition of basic procedural suture skills in medical students according to practical teaching by surgeons versus peers.

\section{Materials and methods}

Pre-experimental study before and after was performed in medical students of the University of
Concepción between November 2017 and December of 2017.

\section{Selection of participants}

The inclusion criteria were to take the subject of surgery during the second semester of 2017 and sign informed consent, 46 students participated, corresponding to $100 \%$ of the section committed to research.

\section{Intervention}

A practical suture workshop of 16 academic hours divided into four face-to-face sessions was held. The participants were randomly distributed in such a way that half of them were trained by subspecialist surgeons while the other half received instruction from medical students previously trained for this purpose (suture instructor).

During the sessions, infiltration of local anesthetics, preparation of surgical field, discontinuous point, continuous point, knots with hand, suture with staples, and removal of points were trained.

Three videos were at disposal to the participants on the institutional website of the university that provided basic theoretical knowledge about surgical techniques. The first video introduces the concept of suture, defines the characteristics of it, and briefly describes the different types of suture that are most frequently used in the clinic. The second video exposes the instrument used in basic surgical procedures and local anesthesia. Finally, the third video includes a tutorial demonstration of infiltration of local anesthetics followed by the technique of continuous and discontinuous stitch suture in the biological model. The duration of each video ranged between 5 and $10 \mathrm{~min}$.

\section{Suture instructors}

The medical students who worked as suture instructor held a training workshop of 28 academic $h$ that consisted of three modules: integral theoretical 
classes, simulation in the biological model, and practice in the operating room, between May 2017 and June in 2017. The participants attended $10 \mathrm{~h}$ of theoretical lectures given by plastic surgeons where they were given extensive knowledge of suture technique, indications, and properties of suture materials, correct performance of aseptic technique, surgical instrument management, and local anesthesia. At the end of the theoretical module, the participants took an assessment of theoretical knowledge, passing with a minimum grade of 6.0 on a scale of 1.0-7.0. Then, the participants received $10 \mathrm{~h}$ of practice in biological simulation model (pig's foot) under the instruction of a cardiothoracic surgeon who gave feedback and gave advice on technique and use of surgical instruments by teaching methodology in small groups. In a third phase, the participants attended for $8 \mathrm{~h}$ at the surgical cardiothoracic surgery ward, with the prior informed consent of the patients, where they perfected their knowledge of different and intradermal sutures, the surgical wound of saphenectomy and sternotomy under the strict supervision of subspecialist surgeons. Surgical wound follow-up was performed postoperatively without evidence of morbidity in patients.

The purpose of this intervention was to train assistant students with more experience and more hours of training in surgical techniques specifically to perform as suture instructor in this research.

\section{Simulation model}

A pig's foot (raw, refrigerated, and not frozen) was used as a biological model to simulate surgical wounds. Each student had an individual position, a wooden board on which the basic surgical and biological model was fixed: Masson Needle Holder, Mayo scissors, dissection forceps, and 2-0 Silk and Polyester sutures.

\section{Training}

The suture workshop was divided into four sessions of 4 academic h, each lasting $45 \mathrm{~min}$. Participants were required to observe the videos with theoretical material described before entering the workshop.

Each participant was presented to the first session with its own biological model of simulation. A wound of four centimeters in length was simulated on the scalp, and anterior side of the thigh, which had to be sutured by the participants only with their knowledge learned in the theoretical videos, by continuous and discontinuous suture technique respectively. Both procedures were recorded on video for all participants and constitute the "pre-workshop" evaluation that reflects the procedural skills students have before the training course.

For the second and third sessions, the participants were divided into eight groups of maximum of six students. Groups were distributed with their respective tutors; the first four groups were trained by subspecialist surgeons (two plastic surgeons, one digestive surgeon, and one cardiothoracic surgeon) and the remaining four groups received instruction by suture instructors.

In the second session, basic skills of the surgical field, local anesthesia technique, manual knots, and discontinuous stitch suture were trained in the biological model. In the third session, continuous point, suture with staples, and removal of points were taught. The tutors actively gave feedback to the participants, correcting immediately the possible errors in the accomplishment of the tasks.

During the fourth session, there was an exclusive time for free practice and consultation of specific concerns with their respective tutors. A final simulation exercise was performed in a biological model in identical conditions to that described for the first session, constituting the evaluation "post-workshop." Again, both procedures were recorded on video.

The pre- and post-workshop evaluations were recorded using the personal mobile phone of each participant and they were delivered to the research team in electronic format. At the end of the workshop, a satisfaction survey was applied on a Likert scale, validated by experts from the Medical Education Department of the University of Concepción. A certificate of participation was given as an incentive to the students who delivered all the videos and answered the satisfaction survey completely.

\section{Workshop evaluation}

The videos of the pre- and post-workshop evaluations were evaluated in random order by two blind specialist surgeons at the time of the intervention and recording. To objectify the progression of the surgical technique learned, the scale "The Objective Structured Assessment of Technical Skills" (OSATS) ${ }^{13}$ was used, which consists of six items on a Likert scale, giving a score of 1 , if the participant does not show mastery of skill, to 5 , if it performs efficiently. 

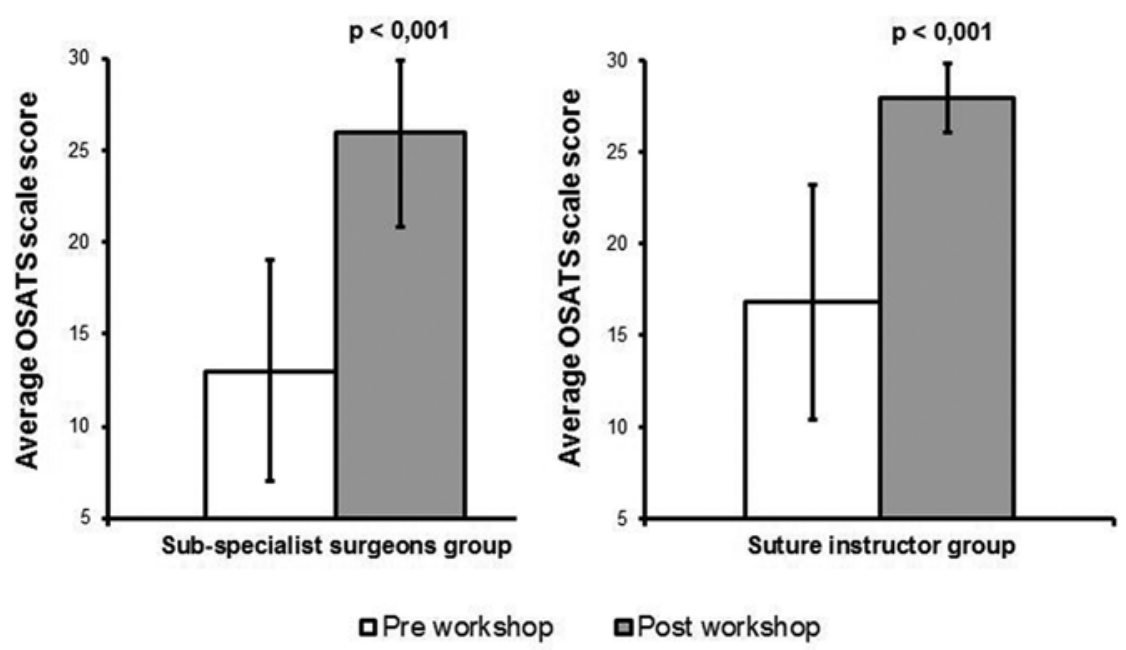

Figure 1. Comparison of pre-workshop versus post-workshop results in a group trained by sub-specialist surgeons and suture instructor.

\section{Statistic analysis}

The data were tabulated in the Excel ${ }^{\circledast}$ spreadsheet and analyzed in the SPSS ${ }^{\circledR}$ version 24 program. The pre- and post-intervention results are shown, detailed by variables evaluated in the OSATS scale and the results of the satisfaction survey. The pre- and post-workshop progress of the group trained by subspecialist surgeons versus suture monitors was compared using the Student's t-test for independent variables, considering $p<0.05$ as significant.

\section{Results}

All the participants completed the four sessions of the suture workshop, delivered the pre- and post-workshop evaluations, and answered the satisfaction survey at the end of the course.

In the evaluation of continuous and discontinuous stitches using the OSATS scale, the group trained by subspecialist surgeons obtained an average of $13.0 \pm$ 6.0 pre-workshop and an average of $26.0 \pm 5.2$ post-workshop, with $p<0.001$. Likewise, the group trained by suture monitors increased their average from $16.8 \pm 6.4$ to $27.9 \pm 2.1$ in the pre- versus post-workshop evaluation, respectively, with $p<0.001$ (Fig. 1). The differences of post-workshop evaluation between both groups were not statistically significant (Fig. 2).

All the variables evaluated in the OSATS scale showed a significant increase in the qualification at the end of the training. In both groups, "planning and rhythm" reached the highest score while "time and motor" obtained the lowest performance. However, the percentage of achievement of each of the procedural

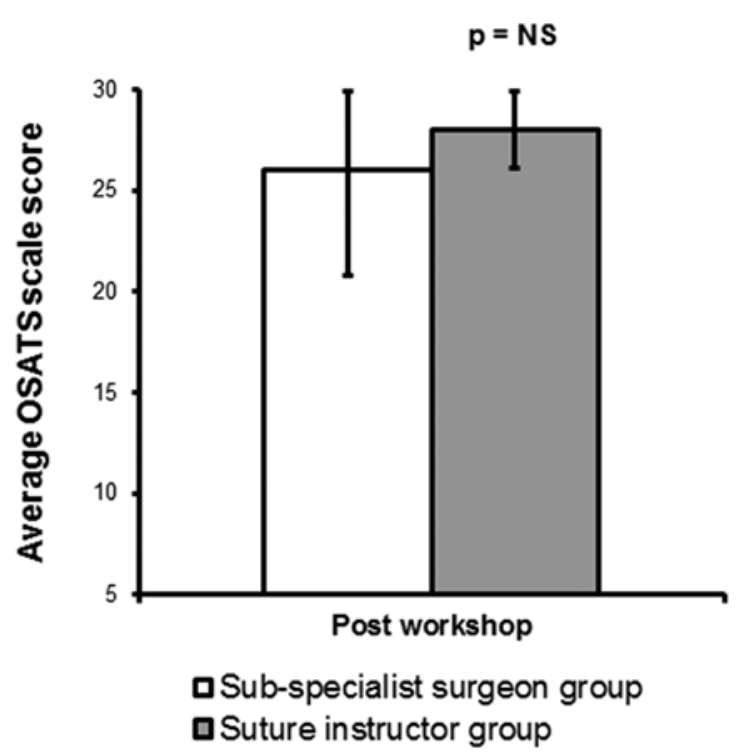

Figure 2. Post-workshop results in a group trained by surgeons versus monitors.

skills evaluated by the OSATS scale exceeds $80 \%$ at the end of the workshop without significant differences between the group trained by sub-specialist surgeons and suture instructors (Fig. 3).

The results of the satisfaction survey are shown in Table 1. Particularly, the evaluation items regarding knowledge and empathy of the tutor were highly qualified, without significant differences when comparing the training by subspecialist surgeons versus suture monitors. Likewise, there are no significant differences between the groups when comparing the perception regarding the general organization of the workshop, available audiovisual material, or the quality of the instruments available for this workshop. 
Table 1. Results of satisfaction survey according to teaching by sub-specialist and suture instructor

\begin{tabular}{|c|c|c|c|}
\hline Item & $\begin{array}{l}\text { Sub-specialist surgeons group } \\
\qquad(\mathrm{n}=23)\end{array}$ & $\begin{array}{l}\text { Suture instructor group } \\
\qquad(n=23)\end{array}$ & p Value \\
\hline The suture workshop activity was well organized & $3.91 \pm 0.3$ & $3.78 \pm 0.42$ & $p=0.1$ \\
\hline $\begin{array}{l}\text { The theoretical information of the audio-visual material delivered prior } \\
\text { to the workshop seemed appropriate }\end{array}$ & $3.09 \pm 0.67$ & $3.30 \pm 0.58$ & $p=0.1$ \\
\hline The workshop had clear objectives & $4.0 \pm 0$ & $4.0 \pm 0$ & $p=0.5$ \\
\hline $\begin{array}{l}\text { The suture workshop seemed relevant to my training as a general } \\
\text { practitioner }\end{array}$ & $4.0 \pm 0$ & $3.96 \pm 0.21$ & $p=0.2$ \\
\hline $\begin{array}{l}\text { Participation in the suture workshop improved my basic technical } \\
\text { skills of surgery }\end{array}$ & $3.96 \pm 0.21$ & $3.96 \pm 0.21$ & $p=0.5$ \\
\hline $\begin{array}{l}\text { The practical workshop allowed me to better internalize the } \\
\text { procedure that I was theoretically taught in audio-visual material }\end{array}$ & $3.96 \pm 0.21$ & $4.0 \pm 0$ & $p=0.2$ \\
\hline $\begin{array}{l}\text { Active participation in my workshop group allowed me to achieve a } \\
\text { better learning }\end{array}$ & $4.0 \pm 0$ & $4.0 \pm 0$ & $p=0.5$ \\
\hline The model was suitable for the practice of sutures & $3.70 \pm 0.47$ & $3.83 \pm 0.39$ & $p=0.2$ \\
\hline $\begin{array}{l}\text { The workshop carried out allowed me to realize how I should carry } \\
\text { out my work in the future }\end{array}$ & $3.70 \pm 0.47$ & $3.91 \pm 0.29$ & $p=0.3$ \\
\hline $\begin{array}{l}\text { The students of my workshop group actively participated during the } \\
\text { realization of the suture workshop }\end{array}$ & $4.0 \pm 0$ & $4.0 \pm 0$ & $p=0.5$ \\
\hline $\begin{array}{l}\text { I would like to carry out other practical workshops to learn different } \\
\text { procedures during the race }\end{array}$ & $4.0 \pm 0$ & $4.0 \pm 0$ & $p=0.5$ \\
\hline The instructors were safe and with clear knowledge & $3.96 \pm 0.21$ & $3.87 \pm 0.34$ & $p=0.1$ \\
\hline $\begin{array}{l}\text { The instructors clearly explained the different topics addressed in the } \\
\text { workshop }\end{array}$ & $3.91 \pm 0.29$ & $3.91 \pm 0.29$ & $p=0.5$ \\
\hline I felt that the tutors or monitors were empathic during the workshop & $4.0 \pm 0$ & $4.0 \pm 0$ & $p=0.5$ \\
\hline $\begin{array}{l}\text { The material that the department of surgery made available seemed } \\
\text { sufficient for the realization of the workshop }\end{array}$ & $3.74 \pm 0.54$ & $3.83 \pm 0.49$ & $p=0.3$ \\
\hline I would recommend this workshop to other medical students & $4.0 \pm 0$ & $4.0 \pm 0$ & $p=0.5$ \\
\hline I would like to attend a course that prepares me to be a suture monitor & $3.65 \pm 0.65$ & $3.61 \pm 0.58$ & $p=0.4$ \\
\hline
\end{tabular}

\section{Discussion}

The types of simulators most frequently used for the teaching of surgical techniques include synthetic models, live animals, corpses, and a virtual reality-based simulator. Each of them has advantages and disadvantages which are inherent to the characteristics of each model and its use in undergraduate training courses depend on factors such as available financial resources, number of students to train, and ethical considerations ${ }^{14}$.

The synthetic models ${ }^{15}$ and non-living biological ${ }^{7}$ such as the pig's foot have proved useful for evaluating basic suture techniques in medical students, but not live, or computational animal models that have maximum efficiency in the development of skills complex surgeries, mainly laparoscopic surgery fellows ${ }^{16-19}$.
Our work shows that undergraduate medical students are able to learn basic suture techniques in the biological model and progress their skills statistically significant at the end of a suture workshop, regardless of whether they are trained by subspecialist surgeons or medical students previously trained (suture instructors).

In addition, peer training was well perceived by participants trained by undergraduate students. No significant differences were observed in the main items related to the competence of the tutor, which reaffirms the benefits of including assistant students to training workshops for medical students.

In 1994 Moust and Schmidt concluded that the inclusion of students as assistants in undergraduate teaching creates an educational environment of less emotional stress and motivates students to consult their doubts more frequently. In concordance, the fact 


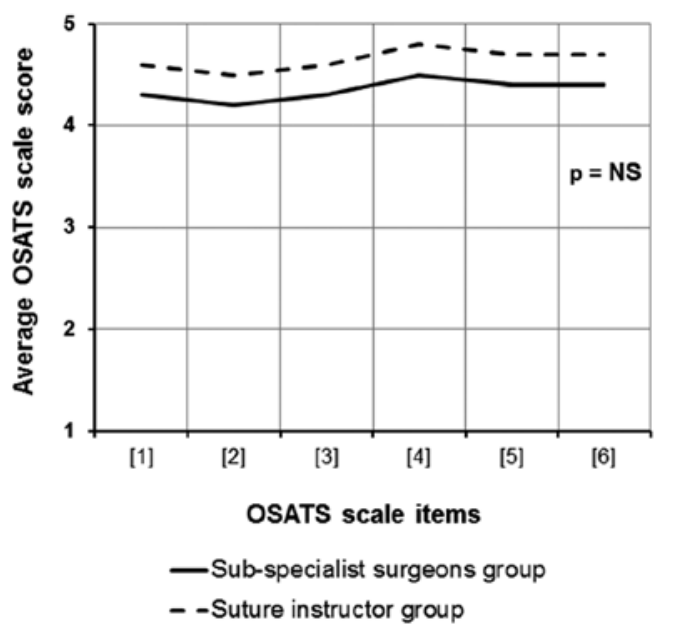

Figure 3. Comparison of results by objective structured assessment of technical skills scale items in training by surgeons versus monitors. [1] Tissue management, [2] time and motor skills, [3] manipulation of instruments, [4] appropriate use of surgical instruments, [5] planning and rhythm, [6] knowledge of the specific procedure.

that the student assistants share the same university career and in a common environment has been associated with greater empathy and understanding of the learning difficulties that the students have, mainly because both groups are exposed to the same pitfalls during their training ${ }^{12,20}$.

On the other hand, teaching by surgeons of different specialties offers additional benefits that are not measurable through the OSATS scale and that can hardly be approved by suture instructors due to their limited experience in specific procedures, so our results do not necessarily show that both groups have equal knowledge regarding all tasks trained during the workshop.

Notwithstanding the foregoing, this intervention constitutes the first approach of medical students to the basic surgical techniques of sutures, motivates each student to improve their skills and solves a fundamental need of medical schools, without implying a risk for patients.

In conclusion, in basic surgical procedures, training by well-trained monitors can be as effective as teaching by subspecialist surgeons, being a methodology well perceived by the students, with excellent results in the final evaluation and without significant differences between the groups compared.

\section{Funding}

This research did not receive any specific grant from funding agencies in the public, commercial, or not-for-profit sectors.

\section{Conflicts of interest}

The authors declare not having any conflicts of interest.

\section{Ethical disclosures}

Protection of human and animal subjects. The authors declare that no experiments were performed on humans or animals for this study.

Confidentiality of data. The authors declare that they have followed the protocols of their work center on the publication of patient data.

Right to privacy and informed consent. The authors declare that no patient data appear in this article.

\section{References}

1. Margolick J, Kanters D, Cameron BH. Procedural skills training for Canadian medical students participating in international electives. Can Med Educ J. 2015;6:e23-33.

2. Ramsey $\mathrm{KM}$, Weijer $\mathrm{C}$. Ethics of surgical training in developing countries. World J Surg. 2007;31:2067-9.

3. Ziv A, Wolpe PR, Small SD, Glick S. Simulation-based medical education: an ethical imperative. Acad Med. 2003;78:783-8.

4. Schooner C. The ethics of learning from patients. CMAJ. 1997;156:535-8.

5. Baker GR, Norton PG, Flintoft V, Blais R, Brown A, Cox J, et al. The Canadian adverse events study: the incidence of adverse events among hospital patients in Canada. CMAJ. 2004;170:1678-86.

6. Sabench F, Hernández M, Muñoz A, Cabrera A, Del Castillo, D. Evaluación de las habilidades quirúrgicas durante el pregrado mediante la introducción de un simulador virtual. Cir Esp. 2013;91:177-83.

7. Torres R, Orban R, Serra E, Marecos M, Vargas L, Deffis L, et al. Enseñanza de técnicas quirúrgicas básicas en simuladores biológicos. Experiencia pedagógica en el pregrado. Educ Méd. 2003;6:149-52.

8. Nousiainen M, Brydges R, Backstein D, Dubrowski A. Comparison of expert instruction and computer-based video training in teaching fundamental surgical skills to medical students. Surgery. 2008:143:539-44.

9. Bodle JF, Kaufmann SJ, Bisson D, Nathanson B, Binney DM. Value and face validity of objective structured assessment of technical skills (OSATS) for work based assessment of surgical skills in obstetrics and gynaecology. Med Teach. 2008;30:212-6.

10. Niitsu $H$, Hirabayashi $N$, Yoshimitsu M, Mimura T, Taomoto J, Sugiyama $Y$, et al. Using the objective structured assessment of technical skills (OSATS) global rating scale to evaluate the skills of surgical trainees in the operating room. Surg Today. 2013;43:271-5.

11. Martin JA, Regehr G, Reznick R, MacRae H, Murnaghan J, Hutchison C, et al. Objective structured assessment of technical skill (OSATS) for surgical residents. Br J Surg. 1997;84:273-8.

12. Moust J, Schmidt H. Effects of staff and student tutors on student achievement. High Educ. 1994;28:471-82.

13. Moorthy K, Munz Y, Sarker SK, Darzi A. Objective assessment of technical skills in surgery. BMJ. 2003;327:1032-7.

14. Reznick RK, MacRae H. Teaching surgical skills changes in the wind. N Engl J Med. 2006;355:2664-9.

15. Alvarado J, Henríquez J, Castillo R, Sosa J, León F, Varas J, et al. Programa pionero de simulación en sutura para estudiantes de medicina de pregrado. Rev Chil Cir. 2015;67:480-5.

16. Castillo R, Buckel E, León F, Varas J, Alvarado J, Achurra P, et al. Effectiveness of learning advanced laparoscopic skills in a brief intensive laparoscopy training program. J Surg Educ. 2015;72:648-53.

17. Horeman T, Sun S, Tuijthof GJ, Jansen FW, Meijerink JW, Dankelman J, et al. Design of a box trainer for objective assessment of technical skills in single-port surgery. J Surg Educ. 2015;72:606-17.

18. Abe T, Raison N, Shinohara N, Shamim Khan M, Ahmed K, Dasgupta P et al. The effect of visual-spatial ability on the learning of robot-assisted surgical skills. J Surg Educ. 2018;75:458-64.

19. Miyasaka KW, Buchholz J, LaMarra D, Karakousis GC, Aggarwal R. Development and implementation of a clinical pathway approach to simulation-based training for foregut surgery. J Surg Educ. 2015;72:625-35.

20. Moust J, Schmidt H. Facilitating small-group learning: a comparison of Student and staff tutors' behavior. Instr Sci. 2018;46:337-55. 